\title{
IAMJ
}

INTERNATIONAL

AYURVEDIC

MEDICAL JOURNAL

\section{A REVIEW ON NUTRITIONAL VALUE AND THERAPEUTIC PROPERTIES OF TILA (SESAMUM INDICUM)}

\author{
Anita Kale (Holey) ${ }^{1}$, Shilpa A. Varade ${ }^{2}$ \\ Associate professor, Dept of Dravyaguna, Shri Ayurved Mahavidyalaya, Nagpur. (India) \\ Associate Professor, Rachana Sharir Dept. Shri Ayurved college Hanuman nagar Nagpur 24
}

\section{Corresponding Author: anitaholey1974@gmail.com}

\section{https://doi.org/10.46607/iamj2709052021}

(Published Online: May 2021)

Open Access

(C) International Ayurvedic Medical Journal, India 2021

Article Received: 30/04/2021 - Peer Reviewed: 05/05/2021 - Accepted for Publication: 07/05/2021

Check for updates

\begin{abstract}
Tila (Sesamum indicum L.) consists of dried seeds of Sesamum indicum Linn. (Fam, Pedaliaceae), a rich source of edible oil. It is belonging to the family Pedaliaceaeis cultivated throughout the plains of India. Most of the oils used in Ayurvedic medicines has sesame oil as a base. Sesame was a major oilseed in the ancient world because of its ease of abstraction, its great stability, and its drought resistance. Sesame seeds have an excellent nutritional value. The seeds are especially high in copper, manganese, calcium, and magnesium. Tila is having Guru, Snigdha guna, madhu rasa, ushna veerya and having Madhur Vipak. The Bhavaprakasha Nighantu describes three types of Tila seeds, viz., black, white and red. Black and white among white variety sesame seeds contain more quantity of lignin compounds. The black sesame seeds are rich in B vitamins and iron. It is also rich in calcium and zinc. These minerals help to support healthy bones, muscles, blood, and nervous system.
\end{abstract}

Keywords: Tila, Rasa, Veerya, Sesamum indicum, Sesame.

\section{INTRODUCTION}

Tila (Sesame) is a one of the ingredients as a food and Spices in Indian food which is used in every household for cooking, religious and medicinal purposes. Tila (Sesamum indicum L.) consists of dried seeds of Sesamum indicum Linn. (Fam, Pedaliaceae), belonging to the family Pedaliaceaeis an erect glandular pubescent, annual herb branching from the base, it is a herb extensively cultivated throughout the plains of India upto $1200 \mathrm{~m}$ for its seeds. Its seed is a rich source of edible oil. ${ }^{1}$ The Bhavaprakasha Nighantu describes only three types of Tila seeds, viz., black, white and red. There are two variety of sesamum 
existing in India. Black and white among white variety sesame seeds contain more quantity of lignin compounds than the black and brown varieties, in which sesamin and sesamolin are the two major lignans. ${ }^{2}$ Both of them having nearly similar chemical composition. White sesame seeds are considered to be better for edible purpose and the black sesame seeds are preferable for use of medical conditions. Sesame oil is the one of the best drugs used for vatashamana. Most of the oils used in Ayurvedic medicines has sesame oil as a base. Sesame was a major oilseed in the ancient world because of its ease of abstraction, its great stability, and its drought resistance. $^{3}$

\section{Objectives:}

1. To review of Tila (Sesamum indicum L.) properties with reference to Ayurveda.

2. To review therapeutics properties and medicinal uses of Tila.

\section{Methodology:}

Source of Data: Conceptual review of Tila (Sesamum indicum L.) has been done form Various Nighantus and Ayurvedic Pharmacopeia of India (API) and other classical Ayurveda books, similarly, review also done from published paper in national and international journals.

\section{Tila (Sesamum indicum L.):}

The Bhavaprakasha Nighantu describes three types of Tila seeds, viz., black, white and red. ${ }^{4}$

\section{SYNONYMS: ${ }^{5}$}

$\begin{array}{ll}\text { Sanskrit } & \text { : Tila } \\ \text { Assamese } & \text { : Simmasim } \\ \text { Bengali } & \text { : Tilagachh } \\ \text { English } & \text { : Sesame, Gingelly-oil Seeds } \\ \text { Gujrati } & \text { : Tall } \\ \text { Hindi } & : \text { Tila, Teel, Tili } \\ \text { Kannada } & \text { : Accheellu, Ellu } \\ \text { Malayalam } & \text { : Ellu } \\ \text { Marathi } & \text { :Tila } \\ \text { Oriya } & : \text { Til } \\ \text { Punjabi } & : \text { Til } \\ \text { Tamil } & \text { : Ellu } \\ \text { Telugu : Nuvvulu } \\ \text { Urdu : Kunjad }\end{array}$

Chemical constituents: Chemical constituents in Tila (sesame seeds) is - around 55\% oils, sesamin, sesamolin, sesamol (3,4- methylenedioxy-phenol), Fatty oils are mainly composed of $48 \%$ of oleiic acid,
$37 \%$ linoleeic acid, palmate acid, stearic acid, archidonic acid. Krishna Tila (black sesame) also contains vitamin E, B-complex vitamins (especially niacin), phytosterols, proteins, sucrose, saccharides, sesamose, and trace amount of phosphorus, potassium and cytochrome C. Tila (black sesame seeds) is very good source of calcium, which has been proved through various studies across the globe.

Sesame Seeds Nutritional Profile: Sesame seeds have a excellent nutritional value. The seeds are especially high in copper, manganese, calcium, and magnesium. Here are some notable vitamins, minerals, and other nutrients from approximately 28-30 gm of Sesame. Sesame protein is rich in sulphuraminoacids, particularly methionine $(2.6-3.5 \mathrm{~g} / 16 \mathrm{~g} / \mathrm{N})$ and tryptophan. It has abundant oleic and linoleic acids. ${ }^{6}$ Manganese $-0.7 \mathrm{mg}$.

Copper $-0.7 \mathrm{mg}$.

Calcium - $277 \mathrm{mg}$.

Iron $-4.1 \mathrm{mg}$

Magnesium - $99.7 \mathrm{mg}$.

Properties \& action: ${ }^{7}$

Guna - Guru, Snigdha

Rasa - Madhur

Anu Rasa- Kashay,Tikta

Veerya - Ushna

Vipaka - Madhur

Action of Til tail:

Til taila is Agneya, Ushna, Tikshna, Madhur rasa, madhur vipaki, Bruhan, Prinana, Vyavayi, Sushma, vishad, vikasi, Twak-prasarak, medhya vardhak, Mardavkar, Mansavardhak, Staryakar, Vranahitkar. Roots and leaves are emollient, and their decoction forms a good hair wash to promote hair growth and blacken them. Externally it is used for dryness of skin. Oil is widely used as ingredient of pharmaceutical industry. The oil is also used in formulation of hair oils.

Important Formulations- Narasimha Churna, Jatiphaladya Churna, Samangadi Churna, Haridradi Lepa, Vrushya, Pupalika Yoga, Nagaradi Yoga, Tiladi Upanaha, Tiladi Yoga, Priyaladi Yoga, Mustadi Upanaha, Sunthyadi Churna, Pathyadi Gutika, Hingvadi Yoga, Paniya Kshara, Bhallatakadi Modaka.

Therapeutic Uses : Ashmari, Akshiroga, Atisara, Amashula, Galaganda, Gulma, Hikka, Krumi, Kshaya, Kasa, Kushtha, Pinasa, Pradara, 
Pratishyaya, Shankhaka, Shakuni Graha, Pravahika, Raktatisara, Svasha, Trusha, Visarpa, , Nadi Vrana, Svitra, Granthi, Upadamsha, Vidaraka, Alasa, Khalitya, Palitya, Kumara, Pitrumeeshagraha, Mutraghata, Dantaroga, Dantaharàa, Vatika Mukharoga, Atidgdha, PleeHaroga, Mushika Dansha, Udvarta, Yonishula, Udara, Vatarakta.

DOSE - Powder 5-10 Gm/Day.

\section{DISCUSSION}

Sesame is used in villages for auspicious occasions, rituals, and marriage ceremonies due to its religious and mythological importance. According to Ayurveda Tila taila (sesame oil) is the best vataharadra$v y a$, black sesame is mostly preferred for purpose of Ayurvedic medicine. It is utilized in the treatment of arshas (piles), vranaropana (wound healing), bhagna (fracture), atisara (diarrhoea), dantaroga (dental diseases), vatashonita (gout), palitya (premature greying of hair), for keshasamvardhana (growth of hair) and dantadaurbalya (dental disorders)etc. Tila can be easily administered as food in form of tila laddu or sweets made up of Tila and jaggery it also acts as hematinic and balya. It is good for increasingly intelligence and hairs, hard to digest improves color cold to touch mitigates vata, produces less quantity of urine increases, intelligence, digestion, kapha and pitta also increases milk and is helpful in wound healing of all the oils, til oil is the best one for strength and Uriction. Oils are generally similar in properties to their source among them the chief is that of Tila., it is useful in procedure for Panchakarma viz. Snehan, basti etc. ${ }^{8}$ A detailed description described in Samhitas like Charaka Samhita, Sushruta samhita, Bhavaprakasha about use of Sesame. Acharya Sushrutha, states that the paste of sesame and Mudga (green gram) and also the soup of Mudga (green gram) is a wholesome diet. ${ }^{9}$ A combination of Tila (Sesame), Masha (Black gram), Ashwagandha (Withania somnifera) mixed with goat's ghee and honey promotes strength, when consumed in the morning. ${ }^{10}$

\section{CONCLUSION}

Tila (Sesamum indicum L.) seed is a rich source of edible oil, similarly it is nutritionally rich oil seed. Its therapeutic properties are useful in treating many ailments, Tila tail is used for many types of treatment during Panchakarma procedure of Ayurveda as in Snehan and Basti. Tila is also useful in many cultural and ritual customs in Indian. Its Agriculture production might increase if it needs to be explored for better utilization, if it is properly cultivating then it's good quality would be available for therapeutic purpose.

\section{REFERENCES}

1. Ayurvedic Pharmacopoeia of India Editor Govt. Of India, Ministry of health and Family Welfare. Dept. of Indian System of Medicine and homeopathy New Delhi (ISMH) Edition 2001, Published by the Controller of Publication Civil lines, Delhi.

2. Kumar Rajesh, Vats Anurag and Pradhan Shailendra. Krishna Tila (Sesamum indicum Linn.): A Rasayana Dravya. The Pharma Innovation Journal 2019; 8(5): 24 28

3. Charaka Samhita with Ayurveda Deepika commentary, Sutra 13/12edited by Vd. J. T. Acharya, Published by Chaukhambha Surabharati Prakashan Varanasi, Reprint edition - 2000, p.144

4. Bedigian D, Harlan JR. Evidence for cultivation of sesame in the ancient world, Economic Botany. 1986; 40(2):137-154

5. Dravyagunvidnyan Edited by Priyavat Sharma published by Chaukhamba Prakashan, Varanasi,2001

6. Over 12 Health Benefits of Sesame Seeds and Sesame Oil Published on February 16, 2013 by council of http://truthisscary.com cited on 26.03.2021

7. V.M. Gogate, Dravya Guna Vidyana: 2003 2nd edition Published by Continental Prakashan, Pune.

8. AshtangaHridaya of Vagbhata with the Sarvangasundara of Arundatta Ayurveda Rasayana of Hemadri commentaries. Annotated by Dr. A. M. Kunte and K. R. Sastri Navne; edited by Pt. H. S. Sastri Pradakara Published by Chaukhambha Surabharati Prakashan, Varanasi, Reprint edition, 1997. (A.H.Chi. 8/188)

9. Sushruta Samhita (English translation and Dalhan's commentary along with critical notes), By Prof. P. V. Sharma, Vol. I-III, published by Chaukhambha Visvabharati, Varanasi, 1st edition, 1999. (Su.Utt 40/115).

10. Vaidya Sodhala, GadaNigraha, Rev. by Indradev Tripathi, Ed. by Ganga Sahai Pandey, Chaukhamba Sanskrit Series, Varanasi, 1968, 3rd edition.2/9/66

\section{Source of Support: Nil Conflict of Interest: None Declared}

How to cite this URL: Anita Kale (Holey) \& Shilpa A. Varade: A Review On Nutritional Value And Therapeutic Properties Of Tila (Sesamum Indicum). International Ayurvedic Medical Journal \{online\} 2021 \{cited May, 2021\} Available from: http://www.iamj.in/posts/images/upload/1108 1110.pdf 